\title{
Tectonic Characteristics of Earthquake Development Zones on the Territory of the Chechen Republic
}

\author{
Idris Bayrakov \\ Chechen State University, 32, A. Sheripov Str., 364907, Grozny, Russia
}

doi: https://doi.org/10.21467/abstracts.93.7

\begin{abstract}
A B S T RA C T
By the nature of the geological structure and seismicity on the territory of Chechnya, two seismic-structural zones are distinguished: the meganticlinorium of the Greater Caucasus and the Tersko-Caspian marginal trough.
\end{abstract}

Meganticlinorium of the Greater Caucasus. The most active seismic zone is the Prikazbek epicenter region, which only partially enters Chechnya and has vigorously manifested itself as 7-point earthquakes $(1915,1932,1947)$. The Prikazbek epicenter region is located in a large crushing zone at the intersection of the latitudinal Buron-Larsky, Adaykom-Kazbeksky faults and the Kazbek transverse deep fault. In the Prikazbek region, several smaller seismic regions are distinguished: \{Borisakho, Cross Pass, Darial Gorge, the area north-east of Mount Kazbek. A particularly active seismic node is Borisakho, where from 1932 to 1962 there were 100 earthquakes classified as class A. There is an active seismic source in the upper reaches of Assa in the same zone. The epicenter zone is located at the foot of the Martinis-Mta mountain (3951 m). In 1938, 1946/1950, 1956, 1957 weak earthquakes were observed here. The entire zone is characterized by the frequency of earthquakes in the same or nearby foci.

The active seismic region is located on the western submersion of the Dagestan wedge, in the Aksai-Chanty Argun interfluve. A number of outbreaks have been known here since the 19th century: Shatoisky, Vedeno, Botlikhsky, Ritlyabsky and others. The outbreak in the vicinity of Shatoi manifested itself with 7-point earthquakes in 1868, 1903, 1933, 1966.

The center in the village has long been known. It is conducted. 5-6-point earthquakes of 1862, 1864, 1865, 1875 are associated with this source. In Vedeno, the epicenters of a whole series of earthquakes were instrumentally defined (1933, 1949, 1953, 1954, 1955).

The Botlikh seismic source has manifested itself in many weak earthquakes of group V intensity $(1952,1956$, 1957). In the past, more significant earthquakes occurred here, as evidenced by numerous paleoseismic phenomena in the form of an abundance of underwater landslide facies. In 1970, during the aftershocks of the Dagestan earthquake in Botlikh, an independent 6-point earthquake occurred.

The Ritlyab hearth (south of Gudermes) is also known for numerous weak earthquakes (1933, 1950, 1954, 1955, 1958, 1960).

Apparently, a very significant, active in the past, seismic source is located in the area of Lake Kezenoy-Am, the dam nature of which is proved. It is possible that the giant landslide dam caused by the earthquake dammed the Horsumu and Kauhi rivers, forming Lake Kezenoi-Am. At present, earthquakes of the V group of intensity $(1952,1954,1957,1960,2008)$ have been recorded in the lake area [9].

Tersko-Caspian marginal deflection. The Tersko-Caspian marginal trough is heterogeneous in seismicity. The internal zone (folded wing) of the deflection is very intense, and the external (platform wing) is characterized by very weak seismicity.

C 2020 Copyright held by the author(s). Published by AIJR Publisher in "Abstracts of The Second Eurasian RISK-2020 Conference and Symposium" April 12- 19, 2020, Tbilisi, Georgia. Jointly organized by AMIR Technical Services LLC, Georgian Technical University, Institute of Geography (Kazakhstan) and Russian Institute of Petroleum Geology and Geophysics.

AijR DOI: $10.21467 /$ abstracts.93 
The Second Eurasian RISK-2020 Conference and Symposium

A special place in the inner zone of the Tersky marginal trough is occupied by the Sunzhenskaya and Terskaya anticlinal zones. Being a zone of Pliocene-Quaternary crest-shaped folding with pronounced differential movements, they are characterized by very frequent earthquakes, usually not exceeding 5-6 points, with the exception of the Gudermes anticline on the Tersky ridge and the Starogroznensky anticline on the Sunzhensky ridge, where earthquakes reach 7 points.

The Gudermes seismic source has manifested itself repeatedly and is known, the most significant 5-6magnitude earthquakes occurred here in 1853, 1872, 1904. Since the establishment of the Grozny seismic station of the Academy of Sciences of the USSR, more accurate instrumental data on earthquakes in the Gudermes region have been available: the epicenters of earthquakes of 1933 have been identified, as well as a swarm of earthquakes of 1950 and 1955 with a magnitude of 31/2-4-41/2, which appeared on the surface $5-6$, and in some cases 7 points.

On November 25, 2014, an earthquake of magnitude 4.3 occurred in the Chechen Republic. The quake epicenter, according to the Euro-Mediterranean seismic center, was located only four kilometers northeast of the village of Dzhalka in the Gudermes district and 25 kilometers east of Grozny.

On the Sunzhensky ridge, Starogroznensky region has maximum seismic activity. The focus is located on the eastern periclinal end of the Sunzhen anticlinal zone, where it is complicated by a major shift. 6-7magnitude earthquakes of 1861, 1868, 1902 are connected with the Starogroznensky center. Later, during the period of instrumental observations, earthquakes of the V group occurred in 1938, 1952, 1963. In 1971, there was a 7-point destructive earthquake.

An earthquake of magnitude 4.9 occurred on Wednesday 02.03.2017 in Chechnya, the Voice of Russia reports. Shocks were recorded in Grozny at 21.30 Moscow time on Wednesday. According to seismologists, the city of Grozny became the epicenter of the earthquake. The shocks occurred at a depth of 33 kilometers. There is currently no evidence of damage or injuries. Information is being collected and processed.

According to eyewitnesses, the earthquake was clearly felt in the center of the capital of Chechnya - many residents, frightened, ran out into the street. The zone of increased seismic activity includes the Urus-Martan depression, the Dattykh ledge, Karabulak-Achaluki, Malgobek. A large number of earthquake epicenters $1 \mathrm{~V}-\mathrm{V}$ of the intensity group are associated with this zone. In 1968, in the area with. Achkhoy-Martan experienced a 6-point earthquake.

The zone of articulation of the folded and platform wings passes in the area of the latitudinal current of the Terek. It has long been distinguished by significant seismicity. In 1853, earthquakes occurred in the villages of Shchedrinskaya and Nikolaevskaya, in 1848 in Shchedrinskaya, Chervlenaya, Nikolaevskaya. Here they repeated in 1869, 1872, 1886. Earthquakes of the $\mathrm{V}$ group of intensity were recorded instrumentally in this zone in the area of the village of Galyugaevskaya $(1935,1950)$, Chernoryaska $(1956,1960)$, and in the region of Adilatar (1962).

The platform wing of the Terek-Caspian trough is characterized by very weak seismicity. Single epicenters of earthquakes of group V intensity are known here: in the area of the city of Georgievsk (1946), the village of Urukhskaya (1954), the village of Kurskaya (1960), the village of Sherstobitova (1967). 